\title{
In Vitro Antitumor Activity of Sesquiterpene Lactones from Lychnophora trichocarpha
}

SAÚDE-GUIMARÃES, D.A. ${ }^{1 *}$; RASLAN, D.S. ${ }^{2}$; OLIVEIRA, A.B. ${ }^{3}$

${ }^{1}$ Laboratório de Plantas Medicinais (LAPLAMED), Departamento de Farmácia, Escola de Farmácia, Universidade Federal de Ouro Preto. Rua Costa Sena, 171, Centro, CEP: 354000-000, Ouro Preto, Minas Gerais, Brazil *saude@ef.ufop.br ${ }^{2}$ Departamento de Química, Instituto de Ciências Exatas, Universidade Federal de Minas Gerais, Belo Horizonte, Brazil. ${ }^{3}$ Departamento de Produtos Farmacêuticos, Faculdade de Farmácia, Universidade Federal de Minas Gerais, Av. Antônio Carlos 6627, Belo Horizonte, Minas Gerais, Brazil.

\begin{abstract}
The sesquiterpene lactones lychnopholide and eremantholide $C$ were isolated from Lychnophora trichocarpha Spreng. (Asteraceae), which is a plant species native to the Brazilian Savannah or Cerrado and popularly known as arnica. Sesquiterpene lactones are known to present a variety of biological activities including antitumor activity. The present paper reports on the evaluation of the in vitro antitumor activity of lychnopholide and eremantholide $\mathrm{C}$, in the National Cancer Institute, USA ( $\mathrm{NCl}$, USA), against a panel of 52 human tumor cell lines of major human tumors derived from nine cancer types. Lychnopholide disclosed significant activity against 30 cell lines of seven cancer types with $\mathrm{IC}_{100}$ (total growth concentration inhibition) values between $0.41 \mu \mathrm{M}$ and $2.82 \mu \mathrm{M}$. Eremantholide $\mathrm{C}$ showed significant activity against 30 cell lines of eight cancer types with $\mathrm{IC}_{100}$ values between $21.40 \mu \mathrm{M}$ and $53.70 \mu \mathrm{M}$. Lychnopholide showed values of lethal concentration $50 \%\left(\mathrm{LC}_{50}\right)$ for 30 human tumor cell lines between 0.72 and $10.00 \mu \mathrm{M}$, whereas eremantholide $C$ presented values of $L C_{50}$ for 21 human tumor cell lines between 52.50 and $91.20 \mu \mathrm{M}$. Lychnopholide showed an interesting profile of antitumor activity. The $\alpha$-methylene- $\gamma$-lactone present in the structure of lychnopholide, besides two $\alpha, \beta$ unsaturated carbonyl groups, might be responsible for the better activity and higher cytotoxicity of this compound in relation to eremantholide $\mathrm{C}$.
\end{abstract}

Keywords: Lychnopholide, eremantholide C, sesquiterpene lactones, Lychnophora trichocarpha, antitumor.

RESUMO: Atividade antitumoral in vitro de lactonas sesquiterpenicas de Lychnophora. As lactonas sesquiterpênicas licnofolida e eremantolida $C$ foram isoladas de Lychnophora trichocarpha Spreng. (Asteraceae), espécie vegetal nativa do cerrado brasileiro e popularmente conhecida por arnica brasileira. As lactonas sesquiterpênicas são conhecidas por apresentarem variadas atividades biológicas, incluindo atividade antitumoral. O presente artigo relata a avaliação da atividade antitumoral in vitro de licnofolida e eremantolida $C$ frente a um painel de 52 linhagens de células tumorais, provenientes de tumores humanos referentes a nove principais tipos de câncer. Os testes foram conduzidos no National Cancer Institute, USA ( $N C l$, USA). Licnofolida apresentou atividade significativa frente a 30 linhagens de células tumorais referentes a sete tipos de câncer, com valores de $\mathrm{Cl}_{100}$ (concentração que inibe $100 \%$ do crescimento celular) entre $0,41 \mu \mathrm{M}$ e $2,82 \mu \mathrm{M}$. Eremantolida $\mathrm{C}$ mostrou atividade significativa frente a 30 linhagens de células tumorais referentes a oito tipos de câncer, com valores de $\mathrm{Cl}_{100}$ entre 21,40 $\mu \mathrm{M}$ e 53,70 $\mu \mathrm{M}$. Licnofolida apresentou valores de concentração letal $50 \%\left(\mathrm{CL}_{50}\right)$ para 30 linhagens de células tumorais humanas entre 0,72 e 10,00 $\mu \mathrm{M}$, enquanto eremantolida $C$ mostrou valores de $C L_{50}$ para 21 linhagens entre 52,50 e 91,20 $\mu \mathrm{M}$. Licnofolida apresentou um interessante perfil de atividade antitumoral. A presença na estrutura química da licnofolida de uma $\alpha$-metileno- $\gamma$-lactona, além de dois grupos ésteres $\alpha, \beta$-insaturados, podem ser responsáveis pela melhor atividade e maior citotoxicidade desta substância em relação à eremantolida $C$.

Palavras-chave: Licnofolida, eremantolida C, lactonas sesquiterpênicas, Lychnophora trichocarpha, antitumoral.

Recebido para publicação em 13/04/2012 


\section{INTRODUCTION}

Sesquiterpene lactones are natural products occurring in many plant families, but most widely distributed within the Asteraceae (Bohlmann et al., 1980). These substances are known to present a variety of biological effects including antitumor activity (Rodrigues et al., 1976).

Lychnophora trichocarpha Spreng. (Asteraceae), popularly known as Brazilian arnica, is a bush native to Brazil. Ethanol extract of species of this genus are used in Brazilian folk medicine to treat bruise, pain, rheumatism and inflammatory diseases (Saúde et al., 1998).

The sesquiterpene lactones lychnopholide (1) and eremantholide C (2) were isolated from L. trichocarpha and occur also in other species of Asteraceae (Saúde et al., 1998; Bohlmann \& Jakupovic, 1990). We have previously reported on the trypanocidal, antifungal and antibacterial activities of compounds 1 and $\mathbf{2}$ (Oliveira et al., 1996; Barrero et al., 2000; Saúde et al, 2002). Lychnopholide and eremantholide $\mathrm{C}$ were reported to show anti-hyperuricemic activity and were also found to inhibit monosodium urate crystals-induced paw oedema in mice (de Souza et al., 2012). Lychnopholide and eremantholide $\mathrm{C}$ were able to reduce the carrageenan-induced paw oedema when ointment formulations were administered topically to mice. The anti-inflammatory effect of lychnopholide seems to involve the inhibition of NO production and increase IL-10 production. The mechanism of the effect of eremantholide $C$ on the reduction of carrageenan-induced paw oedema may be attributed to inhibition of TNF- $\alpha$ production and stimulation of IL-10 production. Lychnopholide increased production of TNF- $\alpha$ (Ferrari et al., 2013) and showed potent cytotoxicity against HT-29 human colon cancer cells line besides exhibiting NF $\kappa B$ (p65) inhibitory activity (Ren et al., 2012).

In this paper, we report on the in vitro antitumor activity evaluation of sesquiterpene lactones $\mathbf{1}$ and $\mathbf{2}$.

\section{MATERIAL AND METHODS}

\section{Plant material}

Lychnophora trichocarpha Spreng. was collected at Minas Gerais State, Brazil, in August, 1991. A voucher specimen ( $\left.N^{0} 20635\right)$ is deposited at Herbarium of the Instituto de Ciências Exatas e Biológicas, UFOP, Ouro Preto, MG, Brazil.

Preparation of plant extracts and 1 and 2 isolation. The aerial parts of the plant $(14.0 \mathrm{Kg})$ were dried at room temperature, for 1 week, reduced to powder and extracted with ethanol, at room temperature, for 1 week. The solvent was removed under reduced pressure to afford the ethanol extract $(900.0 \mathrm{~g})$. The extract $(900.0 \mathrm{~g})$ was submitted to column chromatography on silica gel eluting with $n$-hexane, $n$-hexane:ethyl acetate (1:1), ethyl acetate and methanol. The fraction eluted with hexane:ethyl acetate $(1: 1)$ presented, in TLC (hexane:ethyl acetate 60:40; cerium sulfate), white spots characteristics of sesquiterpene lactones This fraction was submitted to column chromatography on silica gel and elution with $n$-hexane:ethyl acetate (80:20) afforded compound 1 (4.0 g, colorless solid, $\mathrm{mp} 128-129^{\circ} \mathrm{C}$, ethanol). Elution with $\mathrm{n}$-hexane:ethyl acetate (70:30) yielded 2 (28.0 g, colorless solid, mp $214-215^{\circ} \mathrm{C}$, ethyl acetate). The compounds were identified by NMR spectroscopy and by comparison with spectral literature data (Le Quesne et al. 1978; Bohlmann et al., 1980; Vichnewiski et al., 1989; Saúde et al., 1998; Saúde-Guimarães et al., 2007).

Lychnopholide (1): 2'-metil-2'-butenoato de 2, 3, 3a, 4, 5, 6, 7, 11a-octaidro-6,10-dimetil-3metileno-2,7-dioxo-6,9-epoxiciclodeca[b]-furan-4-ila $\left.\left[3 a R^{*}, 4 S^{*}(z), 6 R^{*}, 10 Z, 11 a R^{*}\right]\right]$.

$\operatorname{IR}(\mathrm{KBr}) \mathbf{n}_{\text {máx. }}\left(\mathbf{c m}^{-1}\right): 2900(\mathrm{CH}), 1770(\mathrm{C}=\mathrm{O}$, $\gamma$-lactone), $1710(\mathrm{C}=\mathrm{O}$, ketone), $1660(\mathrm{C}=\mathrm{C}), 1590$ ( $C=C O R$, furanone), $1450,1370,1350,1300,1270$, 1230, 1140, 1100, 1040, 1030, 950, 920, 880, 850, 820, 760. EIMS, m/z (rel. int.): $358\left(\mathrm{M}^{+}, \mathrm{C}_{20} \mathrm{H}_{22} \mathrm{O}_{6}, 5\right)$, 295 (2), $275\left(\mathrm{M}-\mathrm{COC}_{4} \mathrm{H}_{7}, 6\right), 258\left(\mathrm{M}-\mathrm{C}_{4} \mathrm{H}_{7} \mathrm{CO}_{2} \mathrm{H}\right.$, 2), 239 (2), 232 (10), 220 (5), 206 (5), 189 (5), 167 (10), 155 (5), 149 (34), 141 (5), 127 (7), 113 (12), 97 (20), 85 (41), $83\left(\mathrm{C}_{4} \mathrm{H}_{7} \mathrm{CO}^{+}, 81\right), 71$ (66), 57 (100). ${ }^{1} \mathrm{H}$ NMR $\left(\mathrm{CDCl}_{3}, 400 \mathrm{MHz}\right): \delta 5,72(\mathrm{~s}, \mathrm{H}-2), 6.01-6.00$ (m, H-5), 5.31-5.29 (m, H-6), 3.73-3.71 (m, H-7), 4.52 (ddd, $J=2.0,2.4,12.0 \mathrm{~Hz}, \mathrm{H}-8), 2.30$ (dd, $J$ $=2.0,14.0 \mathrm{~Hz}, \mathrm{H}-9 \mathrm{a}$ ), 2.49 (dd, $J=12.0,14.0 \mathrm{~Hz}$, $\mathrm{H}-9 \mathrm{~b}), 6.21$ (d, $J=2.8 \mathrm{~Hz}, \mathrm{H}-13 \mathrm{a}), 5.44$ (d, $J=2.8$ $\mathrm{Hz}, \mathrm{H}-13 \mathrm{~b}), 1.53$ (s, H-14), 2.08 (t, $J=2.0 \mathrm{~Hz}, \mathrm{H}-15)$, 6.10 (qq, $J=1.6,7.2 \mathrm{~Hz}, \mathrm{H}-3$ '), 1,88 (dq, $J=1.4,7.3$ $\mathrm{Hz}, \mathrm{H}-4$ '), 1.78 (t, J=1.6 Hz, H-5'). ${ }^{13} \mathrm{C}$ NMR $\left(\mathrm{CDCl}_{3}\right.$, $75 \mathrm{MHz}): \delta 204.94$ (C-1), 104.82 (C-2), 186.98 (C-3), 130.43 (C-4), 135.14 (C-5), 81.77 (C-6), 51.27 (C7), 73.08 (C-8), 44.12 (C-9), 89.78 (C-10), 133.84 (C-11), 168.98 (C-12), 124.35 (C-13), 20.78 (C-14), 20.41 (C-15), 167.16 (C-1'), 126.50 (C-2'), 140.80 (C-3'), 20.11 (C-4'), 15.78 (C-5').

Eremantholide C (2): 6,9-epoxi-2H-1,4dioxaciclodeca [c,d] pentaleno-2,7(4aH)-dioxano, 2a, 3, 5, 6, 11a, 11b-hexaidro-3-hidroxi-2a, 6, 10-trimetil-3-(1'-metiletenil)-2aR* ${ }^{*}, 3 S^{*}, 4 a R^{*}, 6 S^{*}$, 10Z, 11aS*, 11bS*).

IR $(\mathrm{KBr})$ v máx. $\left(\mathrm{cm}^{-1}\right): 3450(\mathrm{OH}), 2900$ (CH), 1770 ( $\mathrm{C}=\mathrm{O}, \gamma$-lactone), 1700 ( $\mathrm{C}=\mathrm{O}$, ketone), $1660(\mathrm{C}=\mathrm{C}), 1590$ (C=C-OR, furanone), 1450, 1370, $1350,1320,1270,1220,1200,1150,1100,1060$, 1040, 1000, 960, 920, 810, 730. EIMS, m/z (rel. int.): $346\left(\mathrm{M}^{+}, \mathrm{C}_{19} \mathrm{H}_{22} \mathrm{O}_{6}, 9\right) ; 328\left(\mathrm{M}-\mathrm{H}_{2} \mathrm{O}, 5\right), 302$ 
(M - CO , 5), 277 (2), 260 (3), 245 (1), 234 (46), 219 (8), 206 (6), 189 (7), 175 (5), 165 (25), 149 (4), 135 (21), 122 (26), 111 (6), 95 (72), 77 (8), 69 (100). ${ }^{1} \mathrm{H}$ NMR $\left(\mathrm{CDCl}_{3}, 300 \mathrm{MHz}\right): 5,63$ (s, H-2); 6,04-6,03 (m, H-5); 5,02-4,98 (m, H-6); 2,82 (dd, J = 4,3; 7,1 $\mathrm{Hz}, \mathrm{H}-7$ ); 4,09 (ddd, $\mathrm{J}=2,5 ; 4,3 ; 12,0 \mathrm{~Hz}, \mathrm{H}-8$ ); 2,48 (dd, $J=2,5 ; 13,5 \mathrm{~Hz}, \mathrm{H}-9 \mathrm{a}$ ); 2,00 (dd, $J=12,0 ; 13,5$ $\mathrm{Hz}, \mathrm{H}-9 \mathrm{~b}$ ); 1,18 (s, H-13); 1,45 (s, H-14); 2,05 (t, J = 1,9 Hz, H-15); 5,31 (br s, H-2'a); 5,07 (t, J = 1,6 $\mathrm{Hz}) ; 1,91$ (s, H-3'); 3,79 (s, OH). ${ }^{13} \mathrm{C}$ NMR $\left(\mathrm{CDCl}_{3}\right.$, $75 \mathrm{MHz}$ ): 205,89 (C-1); 104,54 (C-2); 187,27 (C-3); 130,00 (C-4); 134,77 (C-5); 81,46 (C-6); 62,53 (C7); 78,37 (C-8); 43,46 (C-9); 90,24 (C-10); 59,88 (C-11); 175,72 (C-12); 21,94 (C-13); 20,48 (C-14); 20,30 (C-15); 106,09 (C-16); 142,22 (C-1'); 115,80 (C-2'); 19,00 (C-3'). NMR data were assigned with the aid of 2D NMR experiments ${ }^{1} \mathrm{H}-{ }^{-1} \mathrm{H}$ homonuclear correlation (COSY), ${ }^{1} \mathrm{H}-{ }^{13} \mathrm{C}$ direct (HETCOR), and long-range $(\mathrm{HMBC})$ heteronuclear correlations.

\section{Biological assay}

Antitumor activity screening was carried out in the National Cancer Institute ( $\mathrm{NCl}$, USA) according to an in vitro protocol, based on a panel of 52 cell lines of major human tumors, derived from nine cancer types including leukemia, lung, colon, prostate, breast, CNS, melanoma, ovarian and renal tumors. A description of the rationale and methodology for the 52-cell line assay has been presented elsewhere ( $\mathrm{NCl}, \mathrm{USA})$. Approaches to the analysis and display of the data provided by these assays have been described previously ( $\mathrm{NCl}, \mathrm{USA}$ ).

\section{SRB assay}

Viable human tumor cell lines of the cancer screening panel are grown in RPMI 1640 medium containing $5 \%$ fetal bovine serum and $2 \mathrm{mM}$ L-glutamine. For a typical screening experiment, cells are inoculated into 96 well microtiter plates plates in $100 \mu \mathrm{L}$ at plating densities ranging from 5,000 to 40,000 cells/well depending on the doubling time of individual cell lines. The plates were incubated for $24 \mathrm{~h}$ at $37^{\circ} \mathrm{C}, 5 \% \mathrm{CO} 2,95$ $\%$ air and $100 \%$ relative humidity for $24 \mathrm{~h}$ before addition of experimental compounds to ensure that no contamination of the medium had occurred. Frozen solutions in dimethyl sulfoxide of compounds to test are thawed and diluted to twice the desired final maximum test concentration with complete medium containing $50 \mu \mathrm{g} / \mathrm{ml}$ gentamicin. Following compound addition, the plates are incubated for an additional $48 \mathrm{~h}$ at $37^{\circ} \mathrm{C}, 5 \% \mathrm{CO} 2,95 \%$ air, and $100 \%$ relative humidity. For adherent cells, the assay is terminated by the addition of cold TCA and incubated for 60 minutes at $4^{\circ} \mathrm{C}$. The supernatant is discarded, and the plates are washed five times with tap water and air dried to remove TCA. The fixed plates were then left to dry at room temperature for at least $24 \mathrm{~h}$, after which the Sulforhodamine B (SRB) SRB assay was performed. SRB solution (100 $\mu \mathrm{l})$ at solution $(100 \mu \mathrm{l})$ at $0.4 \%(\mathrm{w} / \mathrm{v})$ in $1 \%$ acetic acid is added to each well, and plates are incubated for 10 minutes at room temperature. After staining, unbound dye is removed by washing five times with $1 \%$ acetic acid and the plates are air dried. Bound stain is subsequently solubilized with $10 \mathrm{mM}$ trizma base, and the absorbance is read on an automated plate reader at a wavelength of $515 \mathrm{~nm}$. Using the seven absorbance measurements [time zero, (Tz), control growth, $(\mathrm{C})$, and test growth in the presence of compounds at the five concentration levels (Ti)], the percentage growth is calculated at each of the concentrations levels. Percentage growth inhibition is calculated as:

which $\mathrm{Ti}>/=\mathrm{Tz}$

$[(\mathrm{Ti}-\mathrm{Tz}) /(\mathrm{C}-\mathrm{Tz})] \times 100$ for concentrations for which $\mathrm{Ti}<\mathrm{Tz}$.

$[(T i-T z) / T z] \times 100$ for concentrations for

Three dose response parameters are calculated for each compound. Growth inhibition of $50 \%\left(\mathrm{IC}_{50}\right)$ is calculated from $[(\mathrm{Ti}-\mathrm{Tz}) /(\mathrm{C}-\mathrm{Tz})] \times 100$ $=50$, which is the compound concentration resulting in a $50 \%$ reduction in the net protein increase (as measured by SRB staining) in control cells during the compound incubation. The compound concentration resulting in total growth inhibition $\left(\mathrm{IC}_{100}\right)$ is calculated from $\mathrm{Ti}=\mathrm{Tz}$. The $\mathrm{LC}_{50}$ (concentration of compound resulting in a $50 \%$ reduction in the measured protein at the end of the treatment as compared to that at the beginning) indicating a net loss of cells following treatment is calculated from [(Ti-Tz)/Tz] $x$ $100=-50$. Values are calculated for each of these three parameters if the level of activity is reached; however, if the effect is not reached or is exceeded, the value for that parameter is expressed as greater or less than the maximum or minimum concentration tested ( $\mathrm{NCl}, \mathrm{USA})$.

\section{RESULTS AND DISCUSSION}

Compounds 1 and $\mathbf{2}$ were evaluated in the National Cancer Institute ( $\mathrm{NCl}$, USA) by an in vitro disease-oriented antitumor screen, which determines antitumor effects against a panel of 52 humans tumor cell lines of major human tumors, derived from nine cancer types including leukemia, lung, colon, prostate, breast, CNS, melanoma, ovarian and renal tumors ( $\mathrm{NCl}, \mathrm{USA})$.

Lychnopholide (1) total growth inhibition of 30 human tumor cell lines derived from eighth cancer types (Table 1), showing to be inactive only against prostate and CNS cancer. Lychnopholide showed significant activity against all leukemia human tumor cell lines tested with $\mathrm{IC}_{100}$ values between $0.43 \mu \mathrm{M}$ and 
$1.51 \mu \mathrm{M}$ and one lung (HOP-92, $\left.\mathrm{IC}_{100}=2.19 \mu \mathrm{M}\right)$, five colon (COLO 205, HCT-116, HCT-15, KM-12, SW$620,1.15<\mathrm{IC}_{100}<2.63 \mu \mathrm{M}$ ), three melanoma (LOXIMVI, SK-MEL-5, UACC-62, $0.41<\mathrm{IC}_{100}<2.09 \mu \mathrm{M}$ ), four ovarian (IGROV1, OVCAR-3, OVCAR-4, OVCAR-8, $\left.0.44<I_{100}<2.75 \mu \mathrm{M}\right)$, six renal (786-0, ACHN, CAKI-1, RXF-393, TK-10, UO-31, $0.65<\mathrm{IC}_{100}<2.82 \mu \mathrm{M}$ ) and five breast (MCF7, MDAMB-231/ATCC, MDA-MB-435, MDA-N, BT-549, $1.41<I C_{100}<2.19 \mu \mathrm{M}$ ) human tumor cell lines tested. Eremantholide C (2) total growth inhibition of 30 human tumor cell lines and was inactive only against prostate cancer (Table 2).
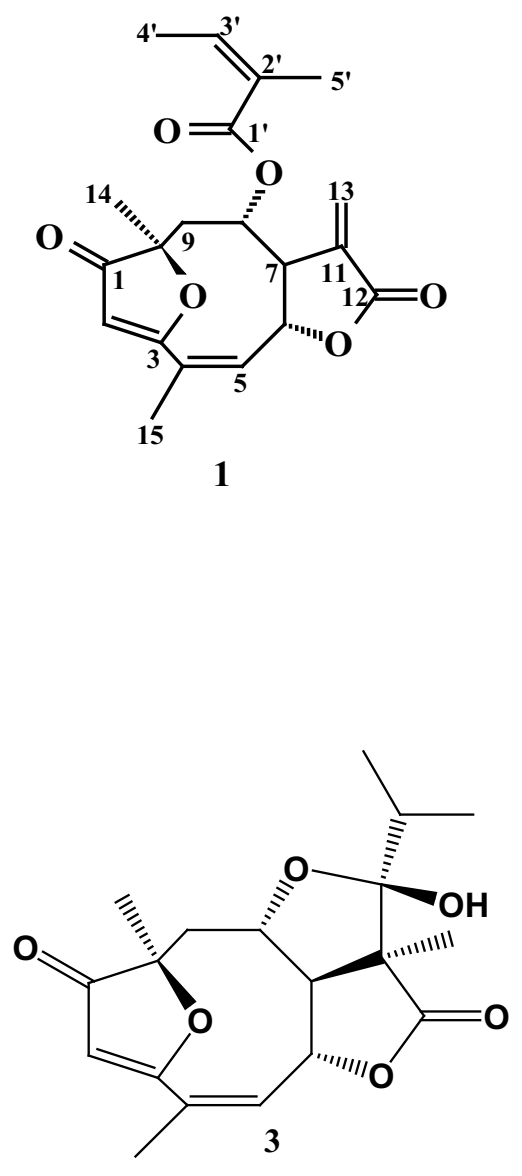

Compound 1 showed higher cytotoxicity than 2 (Figure 1 and 2). Compound 1 presented $\mathrm{LC}_{50}$ values for 30 cell lines between 0.72 and $10.00 \mu \mathrm{M}$, whereas compound 2 showed values for 21 cell lines between 52.50 and $91.20 \mu \mathrm{M}$.

Kupchan and collaborators (1971) reported that cytotoxicity of sesquiterpene lactones is critically dependent upon the presence of the $\alpha$-methylene$\gamma$-lactone moiety. The endocyclic $\alpha, \beta$ - unsatured lactone appears not to confer cytotoxicity and the biological activity is enhanced by the presence of certain additional $\alpha, \beta$-unsaturated carbonyl functions. The majority of the active germacranolides, except
Compound 2 showed significant activity against all leukemia $\left(22.40<\mathrm{IC}_{100}<50.10 \mu \mathrm{M}\right)$ and colon $\left(21.90<\mathrm{IC}_{100}<46.80 \mu \mathrm{M}\right)$ human tumor cell lines tested, besides to present activity against one lung (HOP-92, IC $100=41.70 \mu \mathrm{M})$, one CNS $\left(\mathrm{U}-251, \mathrm{IC}_{100}=37.10 \mu \mathrm{M}\right)$, five melanoma (LOXIMVI, M14, SK-MEL-2, SK-MEL-5, UACC-62, $21.40<\mathrm{IC}_{100}<53.70 \mu \mathrm{M}$ ), two ovarian (OVCAR-3, OVCAR-5, 34.70<IC $100<38.90 \mu \mathrm{M})$, four renal $(786-0$, RXF-393, SN12-C, TK-10, $\left.28.80<\mathrm{IC}_{100}<37.10 \mu \mathrm{M}\right)$ and four breast (MDA-MB-231/ATCC, MDA-N, BT549, T-47D, $\left.30.90<I C_{100}<53.70 \mu \mathrm{M}\right)$ human tumor cell lines tested.
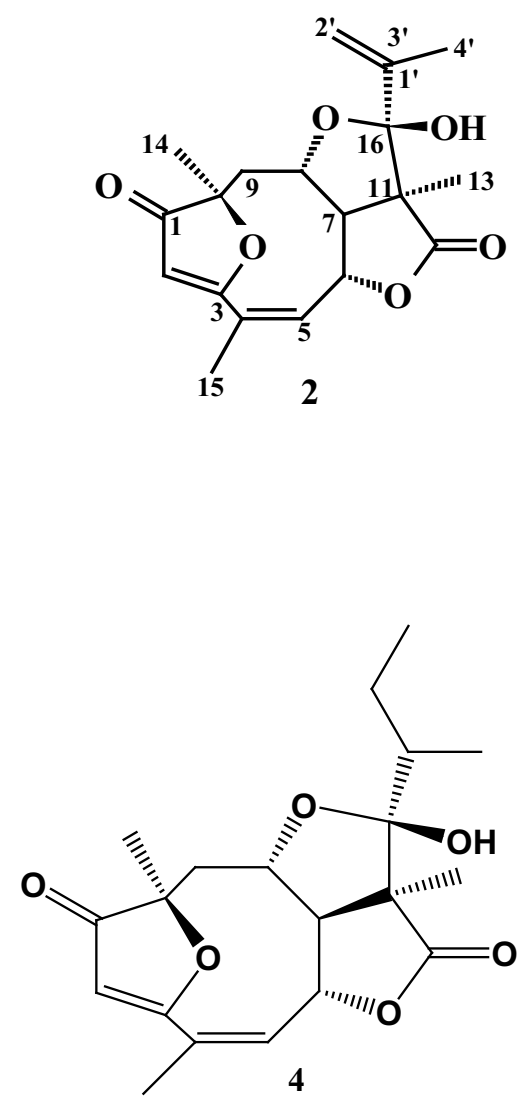

eremantholides, possess double bond conjugated to a lactone carbonyl group. On the basis of this study, the lower activity of $\mathbf{2}$ than $\mathbf{1}$ could be related to the absence of an $\alpha$-methylene- $\gamma$-lactone unity in the structure of 2. Compound $\mathbf{1}$ besides to possess an $\alpha$-methylene- $\gamma$-lactone unity, to present others two $\alpha, \beta$ - unsaturated carbonyl groups. Nevertheless, the eremantholides were less cytotoxic (Mc Dougal et al., 1989).

Other eremantholides, such as eremantholide A (3) and eremantholide B (4), isolated from Eremanthus efaeagnus Schultz-Bip. (Asteraceae), showed significant in vitro inhibitory 
TABLE 1. In vitro antitumor activity showed to lychnopholide (1) against humans tumor cell lines

\begin{tabular}{|c|c|c|c|}
\hline \multirow[b]{2}{*}{ Pannel / Cell Line } & \multicolumn{3}{|c|}{ Concentrations $(\mu \mathrm{M})$} \\
\hline & $\mathrm{IC}_{50}$ & $I C_{100}$ & $\mathrm{LC}_{50}$ \\
\hline \multicolumn{4}{|l|}{ Leukemia } \\
\hline CCRF-CEM & 0.14 & 0.56 & 4.79 \\
\hline HL-60 (TB) & 0.12 & 0.43 & 4.90 \\
\hline K-562 & 0.21 & 1.51 & 49.00 \\
\hline MOLT-4 & 0.21 & 0.98 & - \\
\hline RPMI-8226 & 0.11 & 0.48 & 14.10 \\
\hline SR & 0.13 & 0.54 & 0.72 \\
\hline \multicolumn{4}{|c|}{ Non-Small Cell Lung Cancer } \\
\hline A549/ATCC & 1.02 & 10.00 & 40.00 \\
\hline EKVX & 3.72 & 17.40 & $>100.00$ \\
\hline HOP-62 & 4.27 & 15.80 & 40.00 \\
\hline HOP-92 & 0.54 & 2.19 & 6.46 \\
\hline $\mathrm{NCl}-\mathrm{H} 226$ & 2.19 & 4.27 & 8.13 \\
\hline $\mathrm{NCl}-\mathrm{H} 23$ & 0.87 & 3.02 & 9.55 \\
\hline $\mathrm{NCl}-\mathrm{H} 460$ & 1.51 & 5.25 & 26.3 \\
\hline \multicolumn{4}{|l|}{ Colon cancer } \\
\hline COLO 205 & 0.49 & 2.04 & 6.61 \\
\hline HCC-2998 & 1.66 & 3.09 & 5.89 \\
\hline HCT-116 & 0.42 & 1.74 & 4.57 \\
\hline HCT-15 & 0.24 & 1.02 & 3.98 \\
\hline HT-29 & 0.87 & 3.63 & 24.00 \\
\hline KM12 & 1.07 & 2.63 & 6.46 \\
\hline SW-620 & 0.23 & 1.15 & 5.75 \\
\hline \multicolumn{4}{|l|}{ CNS Cancer } \\
\hline SF-295 & 2.63 & 6.46 & 29.5 \\
\hline SNB-19 & 13.8 & 28.80 & 60.3 \\
\hline U251 & 1.95 & 5.75 & 30.9 \\
\hline \multicolumn{4}{|l|}{ Melanoma } \\
\hline LOX IMVI & 0.17 & 0.41 & 1.00 \\
\hline M14 & 1.29 & 3.55 & 10.00 \\
\hline SK-MEL-2 & 1.35 & 3.16 & 7.41 \\
\hline SK-MEL-5 & 0.50 & 2.09 & 5.62 \\
\hline UACC-257 & 3.39 & 20.40 & 95.5 \\
\hline UACC-62 & 0.28 & 1.70 & 9.12 \\
\hline \multicolumn{4}{|l|}{ Ovarian cancer } \\
\hline IGROV1 & 0.68 & 2.63 & 8.32 \\
\hline OVCAR-3 & 0.36 & 1.44 & 4.27 \\
\hline OVCAR-4 & 1.23 & 2.75 & 6.17 \\
\hline OVCAR-5 & 2.04 & 3.98 & 7.59 \\
\hline OVCAR-8 & 0.18 & 0.44 & 15.10 \\
\hline SK-OV-3 & 4.47 & 18.60 & 51.3 \\
\hline \multicolumn{4}{|l|}{ Renal Cancer } \\
\hline $786-0$ & 0.36 & 1.48 & 3.89 \\
\hline $\mathrm{ACHN}$ & 0.39 & 2.82 & 20.00 \\
\hline CAKI-1 & 0.23 & 0.65 & 3.02 \\
\hline RXF-393 & 0.08 & 1.02 & 4.79 \\
\hline SN12C & 1.44 & 3.31 & 7.76 \\
\hline TK-10 & 0.59 & 1.91 & 4.37 \\
\hline บO-31 & 1.15 & 2.45 & 5.37 \\
\hline Prostate Cancer & & & \\
\hline
\end{tabular}


TABLE 1. In vitro antitumor activity showed to lychnopholide (1) against humans tumor cell lines

\begin{tabular}{llll} 
& \multicolumn{2}{c}{ continuação... } \\
\hline PC3 & 1.35 & 3.98 & 12.90 \\
BU-145 & 3.63 & 14.40 & 41.70 \\
MCF7 & & & \\
MCF/ADR-RES & 0.47 & 1.78 & 6.61 \\
MDA-MB 231/ATCC & 1.44 & 12.9 & $>100.00$ \\
HS 578T & 0.47 & 1.78 & 4.57 \\
MDA-MB-435 & 3.80 & 20.00 & 93.30 \\
MDA-N & $\mathbf{0 . 2 8}$ & $\mathbf{2 . 1 9}$ & 34.70 \\
BT-549 & 0.34 & 1.41 & 4.17 \\
T-47D & 0.48 & 2.19 & 7.41 \\
\hline
\end{tabular}

activity against KB cells (human carcinoma of the nasopharynx) (Raffauf et al., 1975; Le Quesne et al., 1978).

Alkylation of $\alpha, \beta$ - unsaturated carbonyl molecules by biological nucleophiles, in a Michaeltype addition, is considered to be the general mechanism of action (Beekman et al., 1997) of compounds presenting this moiety. In the case of eremantholides, the eletrophilic center, that would be responsible for its antitumor activity, is the carbon five (Mc Dougal et al., 1989). Covalent binding of sesquiterpene lactones to free sulfydryl groups in proteins may interfere with the functions of these macromolecules. Consequently, sesquiterpene lactones would inhibit a large number of enzymes involved in key biological processes, namely DNA and RNA synthesis, protein and purine syntheses, glycolysis, citric acid cycle, and the mitochondrial

TABLE 2. In vitro antitumor activity showed to eremantholide $C(2)$ against humans tumor cell lines

\begin{tabular}{|c|c|c|c|}
\hline \multirow[b]{2}{*}{ Pannel / Cell Line } & \multicolumn{3}{|c|}{ Concentrations $(\mu \mathrm{M})$} \\
\hline & $\mathrm{IC}_{50}$ & $I_{100}$ & $\mathrm{LC}_{50}$ \\
\hline \multicolumn{4}{|l|}{ Leukemia } \\
\hline CCRF-CEM & 5.25 & 26.30 & $>100.00$ \\
\hline HL-60 (TB) & 4.79 & 22.40 & 89.10 \\
\hline K-562 & 6.76 & 33.90 & $>100.00$ \\
\hline MOLT-4 & 15.80 & 50.10 & $>100.00$ \\
\hline RPMI-8226 & 10.50 & 33.90 & $>100.00$ \\
\hline SR & 7.94 & 41.70 & $>100.00$ \\
\hline \multicolumn{4}{|c|}{ Non-Small Cell Lung Cancer } \\
\hline A549/ATCC & 31.60 & $>100.00$ & $>100.00$ \\
\hline EKVX & 41.70 & $>100.00$ & $>100.00$ \\
\hline HOP-62 & 32.30 & $>100.00$ & $>100.00$ \\
\hline HOP-92 & 20.40 & 41.70 & 83.20 \\
\hline $\mathrm{NCl}-\mathrm{H} 226$ & 38.90 & 58.90 & 91.20 \\
\hline $\mathrm{NCl}-\mathrm{H} 23$ & 23.40 & $>100.00$ & $>100.00$ \\
\hline $\mathrm{NCl}-\mathrm{H} 460$ & 19.00 & 58.90 & $>100.00$ \\
\hline \multicolumn{4}{|l|}{ Colon cancer } \\
\hline COLO 205 & 20.40 & 46.80 & $>100.00$ \\
\hline HCC-2998 & 12.30 & 25.70 & 52.50 \\
\hline НСТ-116 & 13.20 & 26.90 & 53.70 \\
\hline HCT-15 & 11.50 & 27.50 & 66.10 \\
\hline HT-29 & 24.00 & 44.70 & 83.20 \\
\hline KM12 & 19.00 & 37.10 & 70.80 \\
\hline
\end{tabular}




\begin{tabular}{|c|c|c|c|}
\hline SW-620 & 6.31 & 21.90 & 74.10 \\
\hline \multicolumn{4}{|l|}{ CNS Cancer } \\
\hline SF-295 & 20.90 & 64.60 & $>100.00$ \\
\hline SNB-19 & $>100.00$ & $>100.00$ & $>100.00$ \\
\hline U251 & 17.40 & 37.10 & 81.30 \\
\hline \multicolumn{4}{|l|}{ Melanoma } \\
\hline LOX IMVI & 5.62 & 21.40 & 60.30 \\
\hline M14 & 19.00 & 53.70 & $>100.00$ \\
\hline SK-MEL-2 & 12.30 & 31.60 & 81.30 \\
\hline SK-MEL-5 & 13.80 & 32.20 & 75.90 \\
\hline UACC-257 & 35.50 & $>100.00$ & $>100.00$ \\
\hline UACC-62 & 14.50 & 38.90 & $>100.00$ \\
\hline \multicolumn{4}{|l|}{ Ovarian cancer } \\
\hline IGROV1 & 22.40 & 61.70 & $>100.00$ \\
\hline OVCAR-3 & 15.80 & 34.70 & 77.60 \\
\hline OVCAR-4 & 30.20 & $>100.00$ & $>100.00$ \\
\hline OVCAR-5 & 19.50 & 38.90 & 77.60 \\
\hline OVCAR-8 & 29.50 & $>100.00$ & $>100.00$ \\
\hline SK-OV-3 & 58.90 & $>100.00$ & $>100.00$ \\
\hline \multicolumn{4}{|l|}{ Renal Cancer } \\
\hline $786-0$ & 15.50 & 28.80 & 53.70 \\
\hline $\mathrm{ACHN}$ & 22.40 & $>100.00$ & $>100.00$ \\
\hline CAKI-1 & 24.50 & 58.90 & $>100.00$ \\
\hline RXF-393 & 10.70 & 30.20 & 85.10 \\
\hline SN12C & 14.80 & 30.90 & 63.10 \\
\hline TK-10 & 20.40 & 37.10 & 67.60 \\
\hline UO-31 & 40.70 & 79.40 & $>100.00$ \\
\hline \multicolumn{4}{|l|}{ Prostate Cancer } \\
\hline PC3 & 19.50 & 67.60 & $>100.00$ \\
\hline DU-145 & 34.70 & $>100.00$ & $>100.00$ \\
\hline \multicolumn{4}{|l|}{ Breast cancer } \\
\hline MCF7 & 18,60 & 33,90 & 60.30 \\
\hline MCF/ADR-RES & 20.00 & $>100.00$ & $>100.00$ \\
\hline MDA-MB 231/ATCC & 14.10 & 32.30 & 74.10 \\
\hline HS 578T & 44.70 & $>100.00$ & $>100.00$ \\
\hline MDA-MB-435 & 21.90 & $>100.00$ & $>100.00$ \\
\hline MDA-N & 10.50 & 40.73 & $>100.00$ \\
\hline BT-549 & 13.50 & 30.90 & 70.80 \\
\hline T-47D & 20.90 & 53.70 & $>100.00$ \\
\hline
\end{tabular}

electron transport chain (Beekman et al., 1997).

\section{CONCLUSIONS}

Lychnopholide (1) showed an interesting profile of antitumor activity. The $\alpha$-methylene- $\gamma$ lactone unity present in the molecule of lychnopholide, besides two $\alpha, \beta$ - unsaturated carbonyl groups, might be responsible for the better activity and higher citotoxicity of this compound than 2. However, eremantholide $\mathrm{C}$ might be an interesting compound to be less cytotoxic. 


\section{ACKNOWLEDGMENT}

The authors thank CNPq, CAPES and FAPEMIG for financial support and National Cancer Institute, Bethesda, Maryland, USA, for in vitro antitumor testing.

\section{REFERENCE}

BARRERO, A.F.; OLTRA, J.E.; ÁLVAREZ, M.; RASLAN, D.S.; SAÚDE DA, AKSSIRA, M. New sources and antifungal activity of sesquiterpene lactones. Fitoterapia, v.71, n.1, p.60-64, 2000.

BEEKMAN, A.C.; WOERDENBAG, H.J.; UDEN, W.V.; PRAS, N.; KONINGS, A.W.T.; WIKSTRÖN, H.V.; SCHIMIDT, T.J.. Structure-Cytotoxicity Relationships of Some Helenanolide Type Sesquiterpene Lactones. Journal of Natural Products, v.60, n.3, p.252-257, 1997.

BOHLMANN, F.; ZDERO, C.; ROBINSON, H.; KING, R.M. Caryophyllene derivatives and a Heliangolide from Lychnophora species. Phytochemistry, v.19, n.11, p.2381-2385, 1980.

BOHLMANN, F. AND JAKUPOVIC, J. Progress in the chemistry of the Vernoniae (Compositae). Plant Systematics and Ecology, Suppl 4, p.3-43, 1990.

BOYD, M.R. Status of the $\mathrm{NCl}$ preclinical antitumor drug discovery screen: Implications for selection of new agents for clinical trial. In, Cancer: Principles and Practice of Oncology Updates. VT DeVita Jr, S. Helmann and SA Rosenberg, Lippincott, Philadelphia, 1989.

KUPCHAN, S.M.; EAKIN, M.A.; THOMAS, A.M. Tumor Inhibitors. 69. Structure-Cytotoxicity Relationships among the Sesquiterpene Lactones. Journal of Medicinal Chemistry, v.14, n.12, p.1147 - 1152, 1971. DE SOUZA, M.R.; DE PAULA, C.A.; RESENDE, M.L.P. ; GRABE-GUIMARÃES, A.; DE SOUZA FILHO, J.D.; SAÚDE-GUIMARÃES, D.A. Pharmacological basis for use of Lychnophora trichocarpha in gouty arthritis: Anti-hyperuricemic and anti-inflammatory effects of its extract, fraction and constituents. Journal of Ethnopharmacology, v. 142, n.3, p. 845-850, 2012. FERRARI, F.C.; FERREIRA, L.C.; SOUZA, M.R.; GRABE-GUIMARAES, A.; PAULA, C.A.; REZENDE, S.A.; SAÚDE-GUIMARÃES, D.A. Anti-Inflammatory
Sesquiterpene Lactones from Spreng. (Brazilian Arnica). Phytotherapy Research, v. 27, n.3, p. 384-389, 2013. LE QUESNE, P.W.; LEVERY, S.B.; MENACHERY, M.D.; BRENNANT, T.F.; RAFFAUF, R.F. Novel Modified Germacranolides and Other Constituents of Eremanthus elaegnus Schultz-Bip. (Compositae). Journal of the Chemical Society, Perkin Transactions 1, n.12, p.1572-1580, 1978.

MC DOUGAL, P.G.; OH, Y.I.; VAN DERVEER, D. Synthesis of the Furanoheliangolide Ring Skeleton. Journal of Organic Chemistry, v.54, n.1, 91-97, 1989.

National Cancer Institute, USA: http://dtp.nci.nih.gov/ branches/btb/ivclsp.html

OLIVEIRA, A.B.; SAÚDE, D.A.; PERRY, K.S.P.; DUARTE, D.S.; RASLAN, D.S.; BOAVENTURA, M.A.D.; CHIARI, E. Trypanocidal sesquiterpenes from Lychnophora species. Phytotherapy Research, v.10, n.4, p.292295, 1996.

RAFFAUF, R.F., HUANG, P.K.C., LE QUESNE, P.W., LEVERY, S.B., BRENNAN, T.F. Eremantholide A, a Novel Tumor-Inhibiting Compound from Eremanthus efaeagnus Schultz-Bip. (Compositae) Journal of the American chemical society, v.97, p.6884-6886, 1975. REN, Y.; ACUÑA, UM.; JIMÉNEZ, F.; GARCÍA, R.; MEJÍA, M.; CHAI, H.; GALLUCCI, J.C.; FARNSWORTH, N.R.; SOEJARTO, D.D.; DE BLANCO, E.J.C.; KINGHORN, A.D. Cytotoxic and NF-kB inhibitory sesquiterpene lactones from Piptocoma rufescens. Tetrahedron, v.68, p.2671-2678, 2012.

RODRIGUES, E.; TOWERS, G.H.N.; MITCHELL, J.C. Biological Activities of Sesquiterpene Lactones. Phytochemistry, v.15, n.11, p.1573-1580, 1976.

SAÚDE, D.A.; BARRERO, A.F.; OLTRA, J.E.; JUSTICIA, J.; RASLAN, D.S.; SILVA, E.A. Atividade Antibacteriana de Furanoeliangolidos. Revista Brasileira de Farmacognosia, v. 12, n. 1, p. 7-10, 2002.

SAÚDE, D.A.; RASLAN, D.S.; SOUZA FILHO, J.D.; OLIVEIRA, A.B. Constituents from the aerial parts of Lychnophora trichocarpha. Fitoterapia, v.69, n.1, p.90-91, 1998.

VICHNEWISKI, W.; TAKAHASHI, A.M.; NASI, A.M.T.; GONÇALVES, D.C.R.G.; DIAS, D.A.; LOPES, J.N.C.; GOEDKEN, V.L.; GUTIÉRREZ, A.B.; HERZ, W. Sesquiterpene Lactones and Other Constituents from Eremanthus seidelii, E. goyazensis and Vanillosmopsis erythropappa. Phytochemistry, v.28, n.5, p.1441-1451, 1989. 